\title{
Variance sources and ratios to estimate energy and nutrient intakes in a sample of adolescents from public schools, Natal, Brazil ${ }^{1}$
}

\section{1}

Fontes e razões de variância para estimar a ingestão de energia e nutrientes de uma amostra de adolescentes de escolas públicas

Severina Carla Vieira Cunha LIMA² Clélia Oliveira LYRA²

Karine Cavalcanti Maurício SENA-EVANGELISTA²

Liana Galvão Bacurau PINHEIRO²

Célia Márcia Medeiros MORAIS²

Betzabeth SLATER ${ }^{3}$

Lucia Fatima Campos PEDROSA²

A B S T R A C T

\section{Objective}

The aim of this study was to describe the sources of dietary variance, and determine the variance ratios and the number of days needed for estimating the habitual diet of adolescents.

\section{Methods}

Two 24 hour food recalls were used for estimating the energy, macronutrient, fatty acid, fiber and cholesterol intakes of 366 adolescents attending Public Schools in Natal, Rio Grande do Norte, Brazil. The variance ratio between the intrapersonal and interpersonal variances, determined by Analysis of Variance, was calculated. The number of days needed for estimating the habitual intake of each nutrient was given by the hypothetical correlation $(r) \geq 0.9$ between the actual and observed nutrient intakes.

${ }^{1}$ Article elaborated from the thesis of SCVC LIMA, entitled: "Nutritional anthropometric status, lipid profile and food consumption as risk factors for cardiovascular disease in adolescents". Universidade Federal do Rio Grande do Norte; 2011.

2 Universidade Federal do Rio Grande do Norte, Centro de Ciências da Saúde, Departamento de Nutrição. R. General Cordeiro de Farias, s/n., 59012-570, Petrópolis, Natal, RN, Brasil. Correspondence to/Correspondência para: SCVC LIMA. E-mail: <scarla@ufrnet.br>.

${ }^{3}$ Universidade de São Paulo, Faculdade de Saúde Pública, Departamento de Nutrição. São Paulo, SP, Brasil. 
160 | SCVC LIMA et al.

\section{Results}

Sources of interpersonal variation were higher for all nutrients and in both genders. Variance ratios were $<1$ for all nutrients and higher in women. Two 24 hour dietary recalls were enough to assess energy, carbohydrate, fiber and saturated and monounsaturated fatty acid intakes accurately. However, the accurate assessment of protein, lipid, polyunsaturated fatty acid and cholesterol intakes required three 24 hour recalls.

\section{Conclusion}

Interpersonal dietary variance in adolescents was greater than intrapersonal variance for all nutrients, resulting in a variance ratio of less than 1 . Two to three 24 hour recalls, depending on gender and the study nutrient, are necessary for estimating the habitual diet of this population.

Indexing terms: Adolescent. Energy intake. Food consumption. Nutrients.

\section{R E S U M O}

\section{Objetivo}

O objetivo deste estudo foi descrever as fontes de variância da dieta, determinar as razões de variâncias e o número de dias necessários para estimar a dieta habitual em adolescentes.

\section{Métodos}

A ingestão de energia, macronutrientes, ácidos graxos, fibra e colesterol foram estimadas por meio de dois recordatórios de 24 horas, aplicados em 366 adolescentes de escolas públicas de Natal, Rio Grande do Norte. A razão de variância foi calculada entre o componente da variância intrapessoal e interpessoal, determinada pela Análise de Variância. A definição do número de dias para a estimativa da ingestão habitual de cada nutriente foi obtida considerando a correlação hipotética de $(r) \geq 0,9$, entre a verdadeira ingestão de nutrientes e a observada.

\section{Resultados}

As fontes de variância interpessoal foram maiores para todos os nutrientes e em ambos os sexos. As razões de variâncias foram < 1 para todos os nutrientes, e mais elevadas no sexo feminino. Dois dias de recordatórios de 24 horas seriam suficientes para avaliar com precisão o consumo de energia, carboidratos, fibra, ácidos graxos saturados e monoinsaturados, exceto para proteínas, lipídeos, ácidos graxos poliinsaturados e o colesterol, que necessitariam de três dias.

\section{Conclusão}

A variância interpessoal da dieta dos adolescentes foi maior do que a intrapessoal, para todos os nutrientes, repercutindo em uma razão de variância menor que 1. Para estimar a dieta habitual nesta população, uma variação de dois a três dias é necessária considerando o sexo e o nutriente avaliado.

Termos de indexação: Adolescente. Ingestão de energia. Consumo de alimentos. Nutrientes.

\section{NTROD U CTION}

Data on food consumption and habitual diet are important in epidemiological studies not only because they allow estimating the energy and nutrient intakes of a population, but also because they demonstrate whether the consumed foods are associated with disease-related outcomes. Assessing habitual food intake is complex because it involves factors related to daily intake variability, information reliability and identification of under- or overreporting ${ }^{1-3}$.
Food intake and variance estimates differ among populations, genders, age groups and cultures $^{4}$. The number of 24 hour food Recalls (24hR) necessary for assessing habitual energy and nutrient intakes accurately remains controversial5-8.

At least two nonconsecutive observation days has generally been suggested. Observation days must be planned considering seasons of the year and different days of the week. With these criteria, it is possible to estimate which intra- and interpersonal variations should be used for defining the number of consumption measures. 
These measures of variance can therefore be used to conduct studies in similar populations $s^{5,6}$. Variance ratios can also be used in population studies where food intake was measured for a single day. In this case, statistical adjustments are recommended to eliminate the effect of intrapersonal variance ${ }^{9}$.

Observed nutrient intakes vary significantly depending on age group ${ }^{10,11}$, gender ${ }^{12}$ and culture, as seen in Russian and American adolescents ${ }^{7}$. Adult period-to-period and day-to-day interpersonal variations contribute significantly to energy and macronutrient intake variations ${ }^{2}$. Brazilian studies that assess the number of $24 \mathrm{hR}$ needed for estimating the habitual intake of adolescents are scarce and have been done only in the country's southeast, in the cities of Piracicaba (São Paulo) ${ }^{13}$ and São Paulo (São Paulo) $)^{14}$. The present study is different because it was done in the Northeast region where the sociocultural and socioeconomic indicators are differences. The aim of this investigation was to describe sources of data variance, and to calculate variance ratios and the number of days needed for estimating the habitual dietary intake of adolescents from the city of Natal, Rio Grande do Norte, Brazil.

\section{METHODS}

A cross-sectional study was conducted with 432 adolescents aged 10 to 19 years, attending municipal schools between April 2007 and November 2008, in Natal, Northeast Brazil. The investigation was approved by the Research Ethics Committee of the Universidade Federal do Rio Grande do Norte (URFN), under protocol $n^{\circ}$ 112/06. All participants provided written Informed Consent prior their inclusion in the study.

Study design, calculation of sample size, sampling and field logistics for data collection have been described elsewhere ${ }^{15}$. A pilot study was done to estimate the prevalence of dyslipidemia and determine sample size. The statistical parameters included an estimated limit of error of $4 \%$ and a sample loss of $30 \%$.
The sample size (483) was defined by stratified sampling with Neyman allocation as follows: $n_{\text {North }}=285 n_{\text {south }}=63 n_{\text {East }}=34 n_{\text {West }}=101$, and the number of schools (21) was given by the mean number of students per school by proportional allocation: $n_{\text {North }}=9 \quad n_{\text {south }}=3 \quad n_{\text {East }}=3$ $\mathrm{n}_{\text {west }}=6$.

\section{Food intake}

Each participant answered two specific 24 hour dietary recalls ${ }^{16}$ at an interval of 30 to 45 days, according to the following criteria: (1) on different days excluding Mondays to avoid recording atypical data; (2) at different times of the month, considering the purchasing power of the families; and (3) at different times of the year due to seasonal foods.

Food intake data were collected by a team trained as recommended by Thompson \& Byers ${ }^{17}$. Interviews were done at the schools.

Food intakes were recorded in cooking units aided by photographs of common foods and two manuals created by the researchers, namely the Household Utensil Measures Manual and the Food Portions Manual.

Despite the limitations associated with administering the $24 \mathrm{hR}$ to 10 -year-olds, the information collected by each $24 \mathrm{hR}$ was double checked to assess interview quality and standardize food portions and recipes. Cooking units and food units were converted to grams, as recommended by the literature ${ }^{18,19}$. Regional and other unusual preparations were made at the Food Technique Laboratory, Department of Nutrition, UFRN.

The energy, macronutrient, Monounsaturated Fatty Acid (MUFA), Polyunsaturated Fatty Acid (PUFA), Saturated Fatty Acid (SFA), fiber and cholesterol contents of the diets were determined by the software Virtual Nutri 2.0 plus $^{20}$. Databanks of food preparations were updated with the inclusion of preparations and the nutritional composition of certain foods. The Food 
162 | SCVC LIMA et al.

Composition Table ${ }^{21}$ and United States Department of Agriculture (USDA) 22 databases were selected because of their more comprehensive and updated nutrition information, including that of regional foods. Nutrition information taken from processed food labels was also used. Participants with an energy intake greater than $5,000 \mathrm{kcal}$ or smaller than $500 \mathrm{kcal}$ were excluded ${ }^{4}$.

\section{Data analysis}

The study databank included the energy, carbohydrate, protein, lipid, MUFA, PUFA, SFA, fiber and cholesterol intake information stored in the Virtual Nutri 2.0 plus software ${ }^{20}$. The software Statistical Package for the Social Sciences (SPSS) 17.0 was used for the statistical analyses. Descriptive analysis (mean and standard deviation) and the skewness-kurtosis test for normality were also used.

Variance components were given by oneway Analysis of Variance (Anova). The Variance Ratio (VR) as calculated by the following formula: $V R=s_{w} 2 / s_{b} 2$, where $s_{w} 2$ is the intrapersonal variance (day-to-day food intake variation of the same individual) and $\mathrm{s}_{\mathrm{b}} 2$ is the interpersonal variance (day-to-day food intake variation between two individuals). The equation proposed by Nelson et al. ${ }^{23}$ was used for estimating correlation coefficient accuracy.

Table 1. Mean and standard deviation of energy and nutrient intakes determined by two 24-hour recalls of adolescents from public schools, according to gender. Natal (RN), Brazil, 2007-2008.

\begin{tabular}{|c|c|c|c|c|c|}
\hline Nutrients & & Mean & SD & Minimum & Maximum \\
\hline \multirow[t]{3}{*}{ Energy (Kcal) } & Total & 1911.4 & 745.6 & 505.6 & 5000.0 \\
\hline & M & 1969.7 & 755.0 & 523.6 & 5000.0 \\
\hline & $\mathrm{F}$ & 1852.4 & 732.3 & 505.7 & 4888.6 \\
\hline \multirow[t]{3}{*}{ Carbohydrates (g) } & Total & 264.4 & 111.4 & 55.3 & 753.9 \\
\hline & $\mathrm{M}$ & 272.1 & 112.1 & 55.3 & 753.9 \\
\hline & $\mathrm{F}$ & 256.7 & 110.2 & 57.8 & 699.4 \\
\hline \multirow[t]{3}{*}{ Lipids (g) } & Total & 62.9 & 30.9 & 9.4 & 249.6 \\
\hline & M & 64.7 & 32.9 & 9.4 & 217.0 \\
\hline & $\mathrm{F}$ & 61.2 & 28.8 & 10.5 & 249.6 \\
\hline \multirow[t]{3}{*}{ Proteins (g) } & Total & 72.0 & 35.0 & 12.7 & 315.2 \\
\hline & M & 75.9 & 36.8 & 20.0 & 315.1 \\
\hline & $\mathrm{F}$ & 68.1 & 32.8 & 12.7 & 200.5 \\
\hline \multirow[t]{3}{*}{ PUFA (g) } & Total & 14.2 & 7.9 & 1.1 & 74.4 \\
\hline & M & 14.7 & 8.1 & 1.1 & 53.5 \\
\hline & $\mathrm{F}$ & 13.7 & 7.6 & 1.2 & 74.4 \\
\hline \multirow[t]{3}{*}{ MUFA(g) } & Total & 18.7 & 10.0 & 1.9 & 89.6 \\
\hline & M & 19.5 & 10.5 & 1.9 & 76.0 \\
\hline & $\mathrm{F}$ & 17.9 & 9.5 & 3.2 & 89.6 \\
\hline \multirow[t]{3}{*}{ SFA (g) } & Total & 20.5 & 11.0 & 2.5 & 74.1 \\
\hline & M & 21.0 & 11.6 & 3.6 & 74.1 \\
\hline & $\mathrm{F}$ & 20.0 & 10.4 & 2.5 & 68.8 \\
\hline \multirow[t]{3}{*}{ Fiber (g) } & Total & 20.6 & 12.9 & 1.9 & 90.5 \\
\hline & M & 21.9 & 13.8 & 2.0 & 90.5 \\
\hline & $\mathrm{F}$ & 19.2 & 12.0 & 2.8 & 77.6 \\
\hline \multirow[t]{3}{*}{ Cholesterol (g) } & Total & 262.5 & 204.6 & 1.0 & 1355.1 \\
\hline & M & 279.3 & 220.9 & 1.0 & 1355.1 \\
\hline & $\mathrm{F}$ & 245.6 & 185.4 & 9.8 & 1131.9 \\
\hline
\end{tabular}

Note: SD: Standard Deviation of the mean; M: Male; F: Female; PUFA: Polyunsaturated Fatty Acids; MUFA: Monounsaturated Fatty Acids; SFA: Saturated Fatty Acids. 
The number of days needed for estimating habitual nutrient intake was based on the hypothetical correlation $(r) \geq 0.9$ between the actual and observed nutrient intake, given by the formula proposed by Black et al. ${ }^{9}$ :

$$
D=\frac{r^{2}}{1-r^{2}} \times \frac{S_{w}^{2}}{S_{b}^{2}}
$$

$D$ is influenced by intrapersonal and interpersonal variance ratios. If the intrapersonal variance observed during the day is smaller than its interpersonal counterpart, a smaller number of repeated measures will be needed. $D$ also depends on the selected $r$. Thus, depending on $r$, the number of study days will be higher or lower.

\section{RE S U L T S}

Of the sample of adolescents $(n=432)$, $83 \%(n=184)$ of the boys and $87 \%(n=182)$ of the girls answered the second $24 \mathrm{hR}$. Boys presented higher mean energy and nutrient intakes but the difference was not significant (Table 1).

Considering all the nutrients, interpersonal sources of variance were greater than intrapersonal sources for both genders. Variance Ratios (VR) were less than one for all the nutrients and higher in the girls (Table 2).

The findings show an " $r$ " close to the hypothetical correlation $(r) \geq 0.9$ for actual and

Table 2. Intrapersonal and interpersonal variations and variance ratio of adolescents from public schools, according to gender, Natal (RN), Brazil, 2007-2008.

\begin{tabular}{|c|c|c|c|c|}
\hline \multirow{2}{*}{ Nutrients } & & \multicolumn{2}{|c|}{ Sources of variance } & \multirow{2}{*}{ VR } \\
\hline & & Intrapersonal & Interpersonal & \\
\hline \multirow[t]{3}{*}{ Energy (Kcal) } & Total & 383593.8 & 728799.3 & 0.53 \\
\hline & $M$ & 376053.3 & 763097.3 & 0.49 \\
\hline & $\mathrm{F}$ & 391313.9 & 682009.9 & 0.57 \\
\hline \multirow[t]{3}{*}{ Carbohydrates (g) } & Total & 8410.9 & 16419.0 & 0.51 \\
\hline & M & 7951.4 & 17175.1 & 0.46 \\
\hline & $\mathrm{F}$ & 8882.9 & 15447.2 & 0.58 \\
\hline \multirow[t]{3}{*}{ Lipids (g) } & Total & 757.9 & 1159.9 & 0.65 \\
\hline & M & 820.0 & 1340.7 & 0.61 \\
\hline & $\mathrm{F}$ & 697.5 & 965.9 & 0.72 \\
\hline \multirow[t]{3}{*}{ Proteins (g) } & Total & 949.8 & 1504.8 & 0.63 \\
\hline & M & 989.1 & 1712.5 & 0.58 \\
\hline & $\mathrm{F}$ & 912.6 & 1233.6 & 0.74 \\
\hline \multirow[t]{3}{*}{ PUFA (g) } & Total & 54.1 & 69.3 & 0.78 \\
\hline & M & 56.6 & 74.9 & 0.76 \\
\hline & $\mathrm{F}$ & 51.8 & 62.4 & 0.83 \\
\hline \multirow[t]{3}{*}{ MUFA (g) } & Total & 78.7 & 122.3 & 0.64 \\
\hline & M & 78.4 & 141.3 & 0.55 \\
\hline & $\mathrm{F}$ & 79.1 & 100.7 & 0.79 \\
\hline \multirow[t]{3}{*}{ SFA (g) } & Total & 90.7 & 151.7 & 0.60 \\
\hline & M & 94.8 & 172.5 & 0.55 \\
\hline & $\mathrm{F}$ & 86.7 & 130.0 & 0.67 \\
\hline \multirow[t]{3}{*}{ Fiber (g) } & Total & 115.7 & 221.7 & 0.52 \\
\hline & M & 124.5 & 254.7 & 0.49 \\
\hline & $\mathrm{F}$ & 107.3 & 180.9 & 0.59 \\
\hline \multirow[t]{3}{*}{ Cholesterol (g) } & Total & 35637.1 & 48080.9 & 0.74 \\
\hline & M & 41495.0 & 56054.1 & 0.74 \\
\hline & $\mathrm{F}$ & 29921.2 & 38849.5 & 0.77 \\
\hline
\end{tabular}

Note: VR: Variance Ratio; M: Male; F: Female; PUFA: Polyunsaturated Fatty Acids; MUFA: Monounsaturated Fatty Acids; SFA: Saturated Fatty Acids. 
164 SCVC LIMA et al.

Table 3. Correlation coefficients and number of days necessary for estimating the habitual energy and nutrient intakes of adolescents from public schools, according to gender, Natal (RN), Brazil, 2007-2008.

\begin{tabular}{|c|c|c|c|}
\hline Nutrients & & $r^{*}$ & Days** \\
\hline \multirow[t]{3}{*}{ Energy (Kcal) } & Total & 0.89 & 2.26 \\
\hline & $\mathrm{M}$ & 0.89 & 2.10 \\
\hline & $\mathrm{F}$ & 0.88 & 2.43 \\
\hline \multirow[t]{3}{*}{ Carbohydrates (g) } & Total & 0.89 & 2.17 \\
\hline & $\mathrm{M}$ & 0.90 & 1.96 \\
\hline & $\mathrm{F}$ & 0.88 & 2.47 \\
\hline \multirow[t]{3}{*}{ Lipids (g) } & Total & 0.87 & 2.77 \\
\hline & $\mathrm{M}$ & 0.88 & 2.60 \\
\hline & $\mathrm{F}$ & 0.86 & 3.07 \\
\hline \multirow[t]{3}{*}{ Protein (g) } & Total & 0.87 & 2.69 \\
\hline & $\mathrm{M}$ & 0.88 & 2.47 \\
\hline & $\mathrm{F}$ & 0.85 & 3.15 \\
\hline \multirow[t]{3}{*}{ PUFA (g) } & Total & 0.85 & 3.33 \\
\hline & $\mathrm{M}$ & 0.85 & 3.24 \\
\hline & $\mathrm{F}$ & 0.84 & 3.54 \\
\hline \multirow[t]{3}{*}{ MUFA(g) } & Total & 0.87 & 2.73 \\
\hline & $M$ & 0.89 & 2.34 \\
\hline & $\mathrm{F}$ & 0.85 & 3.37 \\
\hline \multirow[t]{3}{*}{ SFA (g) } & Total & 0.88 & 2.56 \\
\hline & $\mathrm{M}$ & 0.89 & 2.34 \\
\hline & $\mathrm{F}$ & 0.87 & 2.86 \\
\hline \multirow[t]{3}{*}{ Fiber (g) } & Total & 0.89 & 2.22 \\
\hline & M & 0.90 & 2.09 \\
\hline & $\mathrm{F}$ & 0.88 & 2.51 \\
\hline \multirow[t]{3}{*}{ Cholesterol (g) } & Total & 0.85 & 3.15 \\
\hline & $\mathrm{M}$ & 0.85 & 3.15 \\
\hline & $\mathrm{F}$ & 0.85 & 3.28 \\
\hline
\end{tabular}

Note: ${ }^{*}$ Considering days $=2 ;{ }^{* *}$ considering $r=0.9$.

M: Male; F: Female; PUFA: Polyunsaturated Fatty Acids; MUFA: Monounsaturated Fatty Acids; SFA: Saturated Fatty Acids.

observed nutrient intakes. The number of $24 \mathrm{hR}$ necessary for determining habitual diet and assessing energy and nutrient intakes varied from two to three. Gender affected this finding significantly (Table 3).

\section{DISCUSSION}

The interpersonal variance found by the present study was the greatest source of nutrient intake variance, resulting in a VR of less than 1 and corroborating the findings of Laningan et al. ${ }^{1}$ in children and Herbert et al. ${ }^{24}$ in adults. The lack of variation in habitual dietary intake can be attributed to the low purchasing power and low education levels of the study population. Studies on food intake and dietary patterns done in other regions of Brazil found a VR greater than 1, stemming from higher intrapersonal variance ${ }^{13,14}$. This demonstrates that the daily food intake of an individual is a random event, even though a particular group displays a stable food intake pattern ${ }^{24}$.

The variance ratios of the study sample were lower than those observed in Brazilian adolescents from the cities of São Paulo ${ }^{14}$ and Piracicaba ${ }^{13}$. VR was higher in women, whose pattern was identical to that observed in female adolescents in Russia ${ }^{7}$, but different from the VR found by other studies ${ }^{7,14}$. The best correlations between food consumption and outcome are observed in studies where VR is less than 1. These results are important for creating study designs that use dietary variable correlations as indicators of health and disease ${ }^{7,23}$. Moreover, the findings of the present study, obtained by appropriate statistical methods $25-27$, may be useful for using VR to correct nutrient intake distribution based only on one $24 \mathrm{hR}$ per individual. The use of VR given by population studies with similar characteristics is an alternative to administering several individual $24 \mathrm{hR}$ to estimate habitual diet.

The number of days required for estimating the habitual diet of adolescents as a function of VR varied from two to three, being higher for females, except for energy intake. In both genders, carbohydrates and fibers require fewer study days. Among fatty acids, PUFA requires the highest number of study days and SFA the fewest. Hoffmann et al. ${ }^{5}$ suggested that only two repeated measures of consumption would be necessary for estimating habitual intake, provided that data collection encompasses all seasons and days of the week.

This study did not assess the effect of month or day of the week. However, these variables have little influence on the estimation of the number of days required for determining 
habitual diet. This suggests that day-to-day nutrient intake is random. Therefore, no specific month or day of the week can be recommended ${ }^{14}$. Furthermore, the contribution of macronutrient and total energy intakes during different seasons does not provide additional information ${ }^{28}$.

Accurate assessment of food consumption poses a challenge, mainly due to dietary complexity, whose matrix has widely varying components and external factors. For these reasons, it is difficult to assess food intake without incurring into random and systematic errors, since they are inherent to individuals and the method used $^{4,21,29}$.

In this study, the rigorous methodological approach used for data collection, food intake analysis and databank updating confirms the reliability of the results. When food consumption protocols are monitored more closely, especially during data collection, greater accuracy is achieved and fewer days are necessary for estimating the habitual intake of individuals and populations ${ }^{2}$.

In conclusion, interpersonal variation was greater than intrapersonal variation for all nutrients, resulting in a variance ratio of less than 1. The number of $24 \mathrm{hR}$ needed for determining the habitual diet of adolescents varied from 2 to 3 , depending on nutrient and gender. Estimates of variance ratios found by the present study may be of use in other investigations with adolescents with similar socioeconomic and cultural characteristics.

\section{ACKNOWLEDGEMENTS}

We thank the Pro-Reitoria de Pesquisa, of the Universidade Federal do Rio Grande do Norte, Municipal Secretariat Education of Natal, Rio Grande do Norte, and the nutrition students who participated in data collection: Aline Tuane Oliveira da Cunha, Ingrid Freitas da Silva and Suzylane Annuska Guerra da Silva.

\section{COLLABORATORS}

LFC PEDROSA and SCVC LIMA were responsible for conceiving the study, collecting, analyzing and interpreting data and reviewing the manuscript. CO LYRA, LGB PINHEIRO and CMM MORAIS participated in data collection, analysis and interpretation, and in the review of the final manuscript. KCM SENAEVANGELISTA and B SLATER participated in data analysis and manuscript review.

\section{REFERE N CES}

1. Lanigan JA, Wells JCK, Lawson MS, Cole TJ, Lucas A. Number of days needed to assess energy and nutrient intake in infants and young children between 6 months and 2 years of age. Eur J Clin Nutr. 2004; 58(5):745-50. doi:10.1038/sj.ejcn.160 1872.

2. Grunwald GK, Sullivan DK, Hise M, Donnelly JE, Jacobsen DJ, Johnson SL, et al. Number of days, number of subjects, and sources of variation in longitudinal intervention or crossover feeding trials with multiple days of measurement. Br J Nutr. 2003; 90(6):1087-95. doi: 10.1079/BJN2003989.

3. Anjos LA, Souza DR, Rossato SL. Desafios na medição quantitativa da ingestão alimentar em estudos populacionais. Rev Nutr. 2009; 22(1):151-61. http://dx.doi.org/10.1590/S1415-527320090 00100014

4. Willett WC. Epidemiologia nutricional. $2^{\text {th }} \mathrm{ed}$. New York: Oxford University Press; 1998.

5. Hoffmann K, Boeing H, Dufour A, Volatier JL, Telman J, Virtanen $\mathrm{M}$, et al. Estimating the distribution of habitual dietary intake by short-term measurements. Eur J Clin Nutr. 2002; 56(Suppl 2):53-62. doi: 10.1038/sj/ejcn/1601429.

6. Huybrechts I, De Bacquer D, Cox B, Temme EHM, Van Oyen H, De Backer G, et al. Variation in energy and nutrient intakes among pre-school children: Implications for study design. Eur J Public Health. 2008; 18(5):509-16. doi: 10.1093/eurpub/ckn017.

7. Jahns L, Carriquiry A, Arab L, Mroz TA, Popkin BM. Within- and between-person variation in nutrient intakes of Russian and U.S. children differs by sex and age. J Nutr. 2004; 134(11):3114-20.

8. Presse N, Payette H, Shatenstein B, Greenwood CE, Kergoat MJ, Ferland G. A minimum of six days of diet recording is needed to assess usual vitamin K intake among older adults. J Nutr. 2011; 141(2): 341-46. doi: 10.3945/jn.110.132530. 
9. Black $A E$, Cole TJ, Wiles SJ, White F. Daily variation in food intake of infants from 2 to 18 months. Hum Nutr Appl Nutr. 1983; 37(6):448-58.

10. Salles-Costa R, Barroso GS, Mello MA, Antunes MML, Yokoo EM. Sources of variation in energy and nutrient intakes among children from six to thirty months old in a population-based study. Cad Saúde Pública. 2010; 26(6):1175-86. doi: 10.1590/ S0102-311X2010000600011.

11. Pereira RA, Araujo MC, Lopes TS, Yokoo EM. How many 24-hour recalls or food records are required to estimate usual energy and nutrient intake? Cad Saúde Pública. 2010; 26(11):2101-11. doi: 10.15 90/S0102-311X2010001100011.

12. Erkkola M, Kyttälä P, Takkinen HM, KronbergKippilä C, Nevalainen J, Simell O, et al. Nutrient intake variability and number of days needed to assess intake in preschool children. Br J Nutr. 2011; 106(1):130-40. doi: 10.1017/S000711451000516.

13. Costa MMF, Takeyama L, Voci SM, Slater B, Silva MV. Within- and between-person variations as determinant factors to calculate the number of observations to estimate usual dietary intake of adolescents. Rev Bras Epidemiol. 2008; 11(4):541-48. doi: 10.1590/S1415-790X2008000400003.

14. Verly Jr E, Fisberg RM, Cesar CLG, Marchioni DML. Sources of variation of energy and nutrient intake among adolescents in São Paulo, Brazil. Cad Saúde Pública. 2010; 26(11):2129-37. doi: 10.1590/S010 2-311X2010001100014.

15. Lima SCVC, Lyra CO, Pinheiro LGB, Azevedo PRM, Arrais RF, Pedrosa LFC. Association between dyslipidemia and anthropometric indicators in adolescents. Nutr Hosp. 2011; 26(2):302-08. doi: 10.3305/nh.2011.26.2.4961.

16. Danelon SM. Estado nutricional, consumo alimentar e estilo de vida de escolares de Campinas - SP [mestrado]. Piracicaba: Universidade de São Paulo; 2007.

17. Thompson FE, Byers T. Dietary assessment resource manual. J Nutr. 1994; 124(11 Suppl):2245s-17s.

18. Pinheiro ABV, Lacerda EMA, Benzecry EH, Gomes MCS, Costa VM. Tabela para avaliação de consumo alimentar em medidas caseiras. $5^{a}$ ed. São Paulo: Atheneu; 2005.

19. Fisberg RM, Villar BS. Manual de receitas e medidas caseiras para cálculo de inquéritos alimentares: manual elaborado para auxiliar o processo de inquéritos alimentares. São Paulo: Signus; 2002.
20. Software de avaliação nutricional. Virtual Nutri Plus [programa de computador]. Versão 2008. São Paulo: USP; 2008.

21. Núcleo de Estudos e Pesquisas em Alimentação. TACO: Tabela de composição de alimentos. $2^{\mathrm{a}}$ ed. Campinas: Unicamp; 2006.

22. United States Department of Agriculture. National nutrient database for standard reference. Washington (DC): USDA; 2004 [cited 2007 Feb 22]. Available from: <http://www.usda.gov/wps/portal/ usdahome>.

23. Nelson M, Black AE, Morris JA, Cole TJ. Betweenand within-subject variation in nutrient intake from infancy to old age: Estimating the number of days requerid to rank dietary intakes with desired precision. Am J Clin Nutr. 1989; 50(1):155-67.

24. Herbert JR, Gupta PC, Mehta H, Ebbeling DB, Bhonsle RR, Varghese F. Source of variation in two distinct regions of rural India: Implications of nutrition study design and interpretation. Eur J Clin Nutr. 2000; 54(6):479-86.

25. Beaton GH, Milner J, McGuire V, Feather TE, Little JA. Source of variance in 24-hour dietary recall data: Implications for nutrition study design and interpretation. Carbohydrate sources, vitamins, and minerals. Am J Clin Nutr. 1983; 37(6):986-95.

26. Nusser SM, Carriquiry AL, Dodd KW, Fuller WA. A Semiparametric transformation approach to estimating usual daily intake distributions. J Am Stat Assoc. 1996; 91(436):1440-49.

27. National Research Council. Nutrient adequacy assessment using food consumption surveys. Washington (DC): National Academy Press; 1986.

28. Yannakoulia M, Drichoutis AC, Kontogianni MD, Magkanari F. Season-related variation in dietary recalls used in a paediatric population. J Hum Nutr Diet. 2010; 23(5):489-93. doi: 10.1111/j.1365-27 7X.2010.01049.

29. Beaton GH. Approaches to analysis of dietary data: Relationship between planned analyses and choice of methodology. Am J Clin Nutr. 1994; 59(1 Suppl): 253s-61s.

Received on: 11/4/2012

Final version on: $11 / 10 / 2012$ Approved on: 12/11/2012 